\title{
Penggunaan Alat Peraga Sebagai Upaya Meningkatkan Prestasi Belajar Siswa Dalam Penguasaan Materi Pembelajaran Matematika
}

\author{
Hardik Susilo \\ SDN Karangtengah Prandon 2 Kabupaten Ngawi \\ Hardiksusilo22@gmail.com
}

\begin{abstract}
Abstrak
Untuk bisa mempelajari matematika dengan baik, kita perlu mengerjakannya yakni menggambarkan sesuatu dengan cara sendiri, menunjukkan contohnya, mencoba mempraktekkannya. Penelitian ini menggunakan penelitian tindakan sebanyak 3 putaran. Setiap putaran terdiri dari empat tahap yaitu : rancangan, kegiatan dan pengamatan, refleksi dan revisi. Sasaran penelitian ini adalah siswa kelas IV SDN Karangtengah Prandon 2 dengan jumlah siswa 8 laki-laki dan 6 perempuan dengan tujuan meningkatkan prestasi belajar siswa. Data yang diperoleh berupa hasil tes formatif, data aktivitas siswa dalam pembelajaran serta data pengelolaan pembelajaran. Dari hasil analisis di dapat bahwa prestasi belajar siswa mengalami peningkatan dari siklus I sampai siklus II yaitu rata-rata nilai disiklus I : 7,0 dengan prosentase ketuntasan belajar hanya 70,6 \%. Sedangkan nilai rata-rata disiklus II : 8,1 dengan prosentase ketuntasan belajar $81,47 \%$. Kesimpulan dari penelitian ini adalah penggunaan alat peraga dapat berpengaruh positif terhadap motivasi siswa kelas IV SDN Karangtengah Prandon 2, serta metode ini dapat digunakan sebagai salah satu alternatif pembelajaran Matematika di SD.
\end{abstract}

Kata Kunci: Penggunaan Alat peraga, Prestasi belajar, Matematika

\section{PENDAHULUAN}

Dalam pembelajaran matematika ada dua hal penting yang merupakan bagian dari tujuan pembelajaran matematika adalah pembentukan sifat dengan berpikir kritis dan kreatif. Untuk pembinaan hal tersebut, kita perlu memperhatikan daya imajinasi dan rasa ingin tahu dari anak usia SD. Dua hal tersebut harus dipupuk dan ditumbuh kembangkan. Siswa harus dibiasakan untuk diberi kesempatan bertanya dan berpendapat, sehingga diharapkan proses pembelajaran matematika lebih bermakna. Menghadapi tantangan dan permasalahan tersebut, pendidikan harus berorientasi sesuai dengan kondisi dan tuntutan itu, agar output pendidikan dapat mengikuti perkembangan yang terjadi. Dalam kondisi ini manajemen birokratik sentralistik yang telah menghasilkan pola penyelenggaraan pendidikan yang ragam dalam berbagai kondisi lokal yang berbeda untuk berbagai lapisan masyarakat yang berbeda, tidak bisa dipertahankan lagi. Dikatakan demikian karena muatan dan proses pembelajaran di sekolah selama ini menjadi miskin variasi, berbasis pada standar nasional yang kaku dan diimplementasikan di sekolah atas dasar petunjuk-petunjuk yang cenderung serba detail. Di samping itu peserta didik dievaluasi atas dasar akumulasi pengetahuan yang telah diperolehnya sehingga orang tua tidak mempunyai variasi pilihan atas jasa pelayanan pendidikan bagi anak-anaknya 
sumber-sumber pembelajaran di "dunia" nyata dan unggulan daerah tidak dimanfaatkan bagi kepentingan pendidikan di sekolah dan lulusan hanya mampu menghafal tanpa memahami.

Dalam pembelajaran matematika di SD, guru hendaknya memilih dan menggunakan strategi, pendekatan, metode, dan tehnik yang banyak melibatkan siswa aktif dalam belajar, baik secara mental, fisik, maupun sosial. Dalam pembelajaran matematika siswa dibawa ke arah mengamati, menebak, berbuat, mencoba, mampu menjawab pertanyaan mengapa, dan kalau mungkin mendebat. Prinsip belajar aktif inilah yang diharapkan dapat menumbuhkan sasaran pembelajaran matematika yang kreatif dan kritis.

Pengajaran bahan ajar perlu beragam, bahkan mungkin tidak harus terus menerus dilaksanakan di dalam kelas, tetapi sekalikali kita melaksanakan pembelajaran matematika di luar kelas. Kreativitas guru amat penting untuk mengembangkan modelmodel pembelajaran yang secara khusus cocok dengan kelas yang dibinanya termasuk sarana dan prasarananya. Laporan perbaikan pembelajaran ini penulis buat berdasarkan hasil nilai ulangan tahun pelajaran 20172018. Hasil ulangan bidang studi mata pelajaran Matematika di kelas IV SD Negeri Karangtengah Prandon 2, Kecamatan Ngawi, hasil yang dicapai siswa belum menunjukkan hasil maksimal. Tingkat penguasaan materi masih dibawah $80 \%$. Selama pelajaran berlangsung belum semua siswa aktif dalam suasana pembelajaran mengakibatkan penguasaan siswa terhadap materi pembelajaran sangat kurang. Laporan ini merupakan usaha penulis dalam upaya peningkatan diri dalam pembelajaran. Untuk bisa dipahami oleh semua pihak terkait, penyusunannya telah melalui tahapan yang panjang. Selanjutnya penulis berharap apa yang tersusun dan tersaji dalam laporan ini bisa diterima oleh semua pihak khususnya pembimbing serta dapat ditindak lanjuti dikemudian hari.

\section{METODE}

Pelaksaanan pembelajaran Matematika dilaksanakan di kelas IV SD Negeri Karangtengah Prandon 2, Kecamatan Ngawi Kabupaten Madiun. Adapun jadwal pelaksanaan dari pembelajaran Pra siklus, pembelajaran perbaikan siklus I dan pembelajaran perbaikan siklus II adalah sebagai berikut:

a. Prasiklus dilaksanakan tanggal 3 Maret 2018.

b. Perbaikan Siklus I dilaksanakan tanggal 10 April 2018.

c. Perbaikan Siklus II dilaksanakan tanggal 17 Mei 2018.

Siswa kelas VI SDN Karangtengah Prandon 2, Kecamatan Ngawi Kabupaten Ngawiadalah anak-anak yang rata-rata berumur 10 tahun. Usia tersebut termasuk dalam anak usia sekolah dasar dimana mereka memiliki beberapa karateristik yang menonjol yaitu:

1. Mempunyai rasa ingin tahu yang tinggi akan suatu hal. Karateristik ini menuntut guru untuk dapat selalu mencari inovatif-inovatif baru yang dapat menarik siswa untuk memahami materi pelajaran yang disampaikan.

2. Senang bermain dimana karateristik ini menuntut guru untuk melaksanakan kegiatan pendidikan yang bermuatan permainan.

3. Senang merasakan atau melakukan/memperagakan sesuatu secara langsung. Karateristik ini menuntut guru untuk merancang model pembelajaran yang memungkinkan anak 
terlibat langsung dalam proses pembelajaran.

Pelaksanaan Pembelajaran

Langkah-langkah yang ditempuh pada pembelajaran Pra Siklus adalah :

1. Kegiatan Awal :

- Absensi siswa

- Mengadakan apersepsi

- Menyampaikan topik yang akan dibahas.

2. Kegiatan Inti :

- Guru menjelaskan materi Pecahan dan urutannya

- Guru memberikan kesempatan siswa untuk bertanya.

- Guru mengadakan tanya jawab.

- Siswa menjawab pertanyaan guru.

- Guru memberikan penguatan materi.

3. Kegiatan akhir :

- Guru membagikan lembar tes akhir.

- Siswa mengerjakan soal tes.

- Mencocokkan hasil tes akhir.

- Menutup pelajaran.

Hasil Pengamatan

Pelaksanaan pembelajaran pra siklus diamati oleh teman sejawat untuk membantu meneliti dalam merekam data. Dalam pelaksanaan pembelajaran ditemukan halhal sebagai berikut:

1. Guru hanya menggunakan metode ceramah.

2. Siswa kurang minat dengan materi pelajaran.

3. Dalam menerangkan materi tidak memakai alat peraga.

4. Guru tidak memeriksa pemahaman siswa terhadap materi pelajaran.

5. Nilai tertinggi siswa hanya nilai 7 .

6. Nilai rata-rata kelas 5,6.

Refleksi
Berdasarkan temuan pada proses pembelajaran pra siklus, peneliti berupaya mengadakan rencana perbaikan pada pembelajaran siklus I. Adapun rencana yang disusun adalah:

1. Menggunakan alat peraga yang sesuai dengan materi pembelajaran.

2. Memeriksa pemahaman siswa terhadap materi pelajaran.

3. Memberi penguatan terhadap materi pelajaran.

Perbaikan Pembelajaran Siklus I

a. Tujuan Perbaikan

Tujuan dari perbaikan pembelajaran ini adalah untuk meningkatkan prestasi belajar siswa dalam pembelajaran Matematika dengan materi Pecahan dan urutannya.

b. Pelaksanaan Perbaikan

Langkah-langkah yang ditempuh pada pembelajaran perbaikan Siklus I adalah :

1. Kegiatan Awal

- Absensi siswa

- Menyiapkan alat peraga.

- Mengadakan apersepsi.

- Menyampaikan topik yang akan dibahas.

2. Kegiatan Inti

- Guru menjelaskan materi penjumlahan bilangan bulat dengan mempergunakan alat peraga garis bilangan.

- Guru memberikan contoh pengerjaan soal.

- Guru memberikan latihan soal.

- Membahasa bersama-sama pengerjaan soal.

- Menyimpulkan materi pembelajaran.

3. Kegiatan akhir :

- Guru membagikan lembar tes akhir.

- Siswa mengerjakan soal tes.

- Mencocokkan hasil tes akhir.

- Memberi salam. 
- Menutup pelajaran.

Hasil Pengamatan.

Pelaksanaan perbaikan pembelajaran diamati oleh teman sejawat untuk membantu meneliti dalam merekam data. Dalam pelaksanaan perbaikan pembelajaran siklus I ditemukan hal-hal yang menjadi masalah yaitu:

1. Sebagaian siswa masih belum aktif dalam pembelajaran.

2. Penguasaan siswa terhadap materi pelajaran masih kurang.

3. Siswa yang mendapatkan nilai 8 keatas hanya 5 orang $(25 \%)$.

4. Hasil yang dicapai setelah diadakan evaluasi, nilai rata-rata kelas hanya 7,0.

\section{Refleksi}

Berdasarkan temuan pada proses perbaikan pembelajaran siklus I, peneliti berupaya mengadakan rencana perbaikan pembelajaran siklus II. Adapun rencana yang disusun adalah:

1. Menggunakan alat peraga yang sesuai dengan materi pembelajaran.

2. Memberikan latihan soal melalui LKS.

3. Memberi penguatan terhadap materi pelajaran.

4. Memeriksa pemahaman siswa terhadap materi pelajaran.

Perbaikan Pembelajaran Siklus II

Tujuan dari perbaikan pembelajaran ini adalah untuk meningkatkan prestasi belajar siswa dalam pembelajaran Matematika dengan materi Pecahan dan urutannya.

Langkah-langkah yang ditempuh pada pembelajaran perbaikan Siklus I adalah

1. Kegiatan Awal :

- Absensi siswa

- Menyiapkan alat peraga.
- Mengadakan apersepsi.

- Menyampaikan topik yang akan dibahas.

2. Kegiatan Inti :

- Dengan menggunakan alat peraga garis bilangan, guru menjelaskan tentang materi penjumlahan bilangan bulat.

- Guru memberikan kesempatan bertanya pada siswa tentang materi.

- Guru membagi LKS.

- Siswa mengerjakan LKS.

- Guru bersama siswa membahas LKS.

- Menyimpulkan hasil pengerjaan LKS.

- Guru memberi penguatan.

3. Kegiatan akhir :

- Guru membagikan lembar tes akhir.

- Siswa mengerjakan soal tes.

- Mencocokkan hasil tes akhir.

- Memberi salam.

- Menutup pelajaran.

Hasil Pengamatan

Pelaksanaan perbaikan pembelajaran diamati oleh teman sejawat untuk membantu meneliti dalam merekam data. Dalam pelaksanaan perbaikan hal yang menjadi perhatian khusus adalah alat peraga yang digunakan dan pemberian tugas melalui LKS sangat membantu penguasaan siswa terhadap materi pelajaran. Hal ini terlihat dari keaktipan siswa dalam mengikuti pembelajaran serta peningkatan perolehan nilai dalam tes akhir. Siswa yang mendapatkan nilai 8 keatas sejumlah 12 anak (70\%). Nilai rata-rata kelas dari 7,0 naik menjadi 8,1 . Daya serap materi pelajaran oleh siswa adalah $81 \%$.

HASIL

Deskripsi Temuan dan Refleksi

1. Pra Siklus 
Pada pembelajaran pra siklus melalui refleksi dan diskusi dengan teman sejawat dan supervisor diketahui bahwa faktor penyebab siswa kurang menguasai dan memahami materi pelajaran adalah sebagai berikut:

a. Guru menggunakan metode ceramah yaitu menjelaskan tentang materi penulisan pecahan pada garis bilangan. Siswa hanya mendengarkan penjelasan,dalam pembelajaran ini gurulah yang aktif sedangkan siswa pasif.

b. Sebagaian siswa tidak memperhatikan penjelasan guru karena tidak tertarik dengan materi yang sedang diajarkan. Suasana kelas gaduh karena sebagaian siswa jemu mendengarkan penjelasan guru dan ramai sendiri.

c. Guru tidak menggunakan alat peraga untuk menyampaikan materi pembelajaran mengakibatkan siswa sulit menyerap materi yang di ajarkan.

d. Hasil nilai rata-rata kelas pada tahap pra siklus hanya 5,6.

e. Nilai tertinggi siswa hanya 7 sejumlah 2 anak (10\%).

f. Tingkat penguasaan materi pelajaran hanya $56 \%$.

Tabel Hasil Tes Akhir

Pembelajaran Pra Siklus

\begin{tabular}{|c|l|c|c|}
\hline No & \multicolumn{1}{|c|}{ Nama Siswa } & Nilai & Keterangan \\
\hline 1 & Arga Agung Nur W & 5 & Kurang \\
2 & Daniel Wibowo & 6 & Cukup \\
3 & Alfina Khoirun Nisa & 7 & Baik \\
4 & Anesta Amelia Putri & 6 & Cukup \\
5 & Aventa Rega Christama & 5 & Kurang \\
6 & Yohan Hanif Saputra & 6 & Cukup \\
7 & Andreas Prasetya & 5 & Kurang \\
8 & Nabila Alfa Saroh & 5 & Kurang \\
9 & Bima Putra Ramadani & 6 & Cukup \\
10 & Berlinda Atheriza & 5 & Kurang \\
11 & Putri Nita Marcecilia & 5 & Kurang \\
12 & Moh Ari Dwi Wahyudi & 6 & Cukup \\
13 & Satrio Pinandito & 5 & Kurang \\
14 & Ayu Puji Triastuti & 5 & Kurang \\
\hline
\end{tabular}

\begin{tabular}{|r|c|l|}
\hline Jumlah & 77 & \\
\hline Rata - rata & 5,5 & \\
\hline Nilai Tertinggi & 7 & \\
\hline Nilai Terendah & 5 & \\
\hline Daya Serap & $56 \%$ & \\
\hline
\end{tabular}

Grafik Hasil Tes Akhir

Pembelajaran Pra Siklus

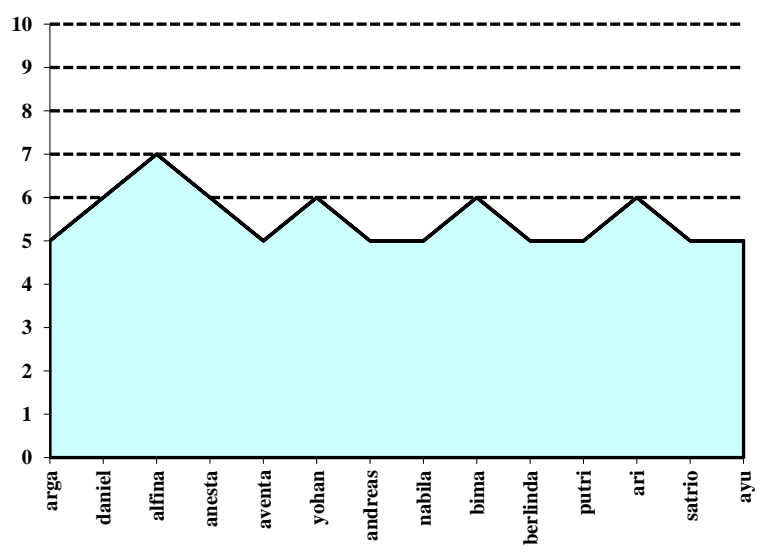

\section{Perbaikan Pembelajaran Siklus I}

Berdasarkan temuan pada pelaksanaan proses perbaikan pembelajaran siklus I, penulis mengadakan diskusi dengan teman sejawat dan supervisor untuk mengatasi permasalahan yang terjadi pada perbaikan pembelajaran siklus I. Kegiatan perbaikan pembelajaran siklus I belum berhasil seperti apa yang diharapkan, karena minat dan perhatian siswa masih kurang, sehingga penguasaan materi pelajaran belum optimal.

Hal ini dapat dilihat dari hasil pengamatan yang dilakukan :

1. Pembelajaran masih bersifat klasikal sehingga suasana kelas masih ramai, hanya sebagaian siswa saja yang memperhatikan penjelasan dari guru.

2. Alat peraga yang digunakan belum mampu menarik minat siswa.

3. Siswa hanya melihat dan mendengarkan penjelasan dari guru.

4. Tidak ada pembentukan kelompok untuk mengaktifkan siswa dalam pembelajaran. Siswa bersifat pasif 
karena hanya mendengarkan penjelasan guru serta melihat media peraga yang dipakai oleh guru.

5. Hasil nilai rata-rata kelas 7,0 .

6. Siswa yang mendapatkan nilai 80 keatas hanya 6 siswa atau (30\%).

7. Daya serap materi pelajaran hanya $70 \%$.

Tabel Hasil Tes Akhir

Perbaikan Pembelajaran Siklus I

\begin{tabular}{|c|l|c|c|}
\hline No & \multicolumn{1}{|c|}{ Nama Siswa } & Nilai & Keterangan \\
\hline 1 & Arga Agung Nur W & 6 & Cukup \\
2 & Daniel Wibowo & 7 & Baik \\
3 & Alfina Khoirun Nisa & 9 & Cukup Baik \\
4 & Anesta Amelia Putri & 8 & Baik \\
5 & Aventa Rega Christama & 6 & Cukup \\
6 & Yohan Hanif Saputra & 7 & Baik \\
7 & Andreas Prasetya & 6 & Cukup \\
8 & Nabila Alfa Saroh & 7 & Baik \\
9 & Bima Putra Ramadani & 8 & Baik \\
10 & Berlinda Atheriza & 6 & Cukup \\
11 & Putri Nita Marcecilia & 6 & Cukup \\
12 & Moh Ari Dwi Wahyudi & 7 & Baik \\
13 & Satrio Pinandito & 7 & Baik \\
14 & Ayu Puji Triastuti & 8 & Baik \\
\hline Jumlah & 98 & \\
\hline Rata - rata & 7,0 & \\
\hline \multicolumn{2}{|l|}{ Nilai Tertinggi } & 9 & \\
\hline \multicolumn{2}{|l|}{ Nilai Terendah } & $70 \%$ & \\
\hline \multicolumn{2}{|l|}{ Daya Serap } & & \\
\hline
\end{tabular}

Grafik Hasil Tes Akhir

Perbaikan Pembelajaran Siklus I

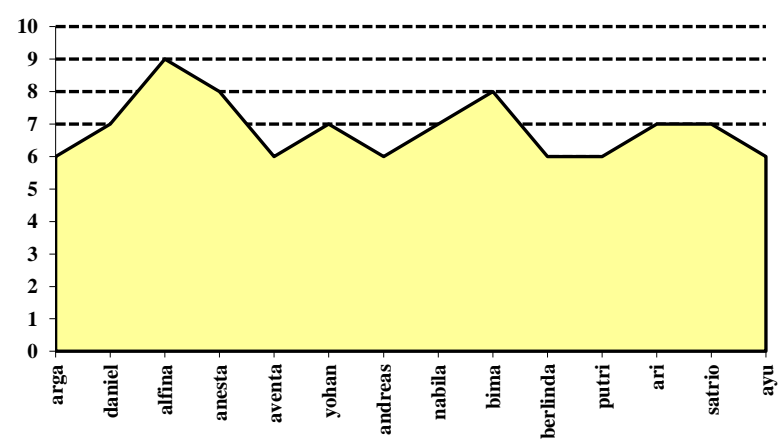

Melihat hal tersebut di atas perbaikan pembelajaran siklus I perlu segera diperbaiki pada perbaikan pembelajaran siklus II.

\section{Perbaikan Pembelajaran Siklus II}

Pada perbaikan pembelajaran siklus II, peneliti mempergunakan alat peraga dalam menyampaikan meteri penulisan pecahan pada garis bilangan. Selain itu peneliti memberi tugas dengan LKS agar siswa dapat aktif dalam mengikuti materi pembelajaran.

Hal ini dapat dilihat dari hasil pengamatan yang dilakukan :

1. Penggunaan alat peraga yang relevan membuat siswa bersemangat dan aktip dalam pembelajaran.

2. Siswa aktif dalam mengikuti pembelajaran. Tugas yang diberikan dapat diselesaikan dengan baik.

3. Siswa dapat menyerap materi pembelajaran dengan alat peraga.

4. Hasil nilai rata-rata adalah 81 .

5. Siswa yang mendapatkan nilai 8 ke atas sejumlah 10 anak (70\%).

6. Tingkat daya serap materi adalah $81 \%$

Tabel Hasil Tes Akhir

Perbaikan Pembelajaran Siklus II

\begin{tabular}{|c|l|c|c|}
\hline No & \multicolumn{1}{|c|}{ Nama Siswa } & Nilai & Keterangan \\
\hline 1 & Arga Agung Nur W & 7 & Baik \\
2 & Daniel Wibowo & 8 & Baik \\
3 & Alfina Khoirun Nisa & 10 & Istimewa \\
4 & Anesta Amelia Putri & 9 & Cukup Baik \\
5 & Aventa Rega Christama & 7 & Baik \\
6 & Yohan Hanif Saputra & 8 & Baik \\
7 & Andreas Prasetya & 7 & Baik \\
8 & Nabila Alfa Saroh & 8 & Baik \\
9 & Bima Putra Ramadani & 9 & Cukup Baik \\
10 & Berlinda Atheriza & 8 & Baik \\
11 & Putri Nita Marcecilia & 7 & Baik \\
12 & Moh Ari Dwi Wahyudi & 8 & Baik \\
13 & Satrio Pinandito & 8 & Baik \\
14 & Ayu Puji Triastuti & 7 & Baik \\
\hline Jumlah & 111 & \\
\hline \multicolumn{2}{|l|}{ Rata - rata } & 8,1 & \\
\hline \multicolumn{2}{|l|}{ Nilai Tertinggi } & 10 & \\
\hline \multicolumn{2}{|l|}{ Dilai Terendah } & 7 & \\
\hline
\end{tabular}


Grafik Hasil Tes Akhir Perbaikan Pembelajaran Siklus II

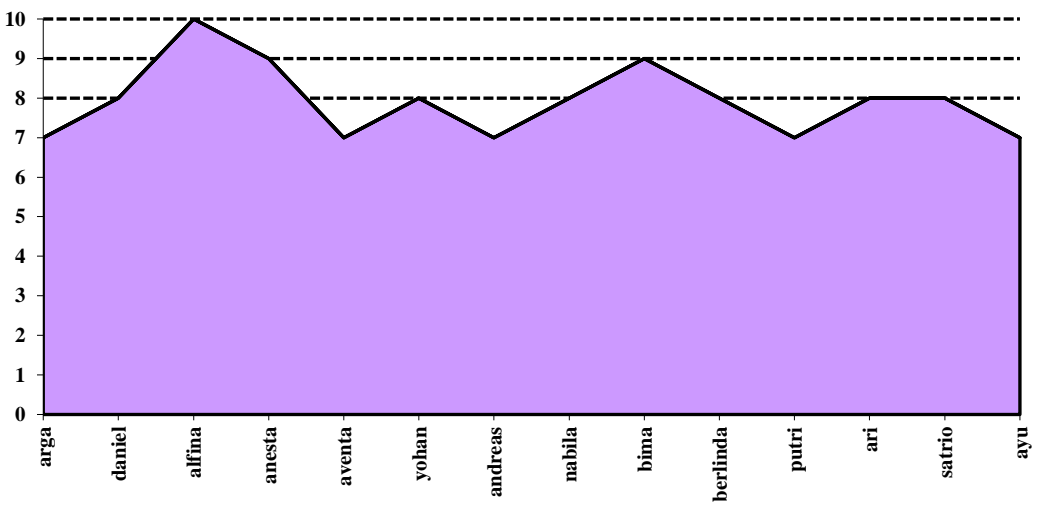

Tabel Perbandingan Hasil Perolehan Nilai Pra Siklus, Siklus I, Siklus II

\begin{tabular}{|c|l|c|c|c|c|}
\hline No & \multicolumn{1}{|c|}{ Nama } & $\begin{array}{c}\text { Pra } \\
\text { siklus }\end{array}$ & Siklus I & Siklus II & Keterangan \\
\hline 1 & Arga Agung Nur W & 5 & 6 & 7 & \\
2 & Daniel Wibowo & 6 & 7 & 8 & Ada Peningkatan \\
3 & Alfina Khoirun Nisa & 7 & 9 & 10 & Ada Peningkatan \\
4 & Anesta Amelia Putri & 6 & 8 & 9 & Ada Peningkatan \\
5 & Aventa Rega Christama & 5 & 6 & 7 & Ada Peningkatan \\
6 & Yohan Hanif Saputra & 6 & 7 & 8 & Ada Peningkatan \\
7 & Andreas Prasetya & 5 & 6 & 7 & Ada Peningkatan \\
8 & Nabila Alfa Saroh & 5 & 7 & 8 & Ada Peningkatan \\
9 & Bima Putra Ramadani & 6 & 8 & 9 & Ada Peningkatan \\
10 & Berlinda Atheriza & 5 & 6 & 8 & Ada Peningkatan \\
11 & Putri Nita Marcecilia & 5 & 6 & 7 & Ada Peningkatan \\
12 & Moh Ari Dwi Wahyudi & 6 & 7 & 8 & Ada Peningkatan \\
13 & Satrio Pinandito & 5 & 7 & 8 & Ada Peningkatan \\
14 & Ayu Puji Triastuti & 5 & 6 & 7 & Ada Peningkatan \\
& & & & & \\
\hline \multicolumn{2}{|l|}{ Jumlah } & 77 & 98 & 111 & Ada Peningkatan \\
\hline \multicolumn{2}{|l|}{ Nata-rata } & 5,5 & 7,0 & 8,1 & Ada Peningkatan \\
\hline \multicolumn{2}{|l|}{ Nilai Tertinggi } & 7 & 9 & 10 & Ada Peningkatan \\
\hline \multicolumn{2}{|l|}{ Taya Serap } & 5 & 6 & 7 & Ada Peningkatan \\
\hline
\end{tabular}

Grafik Perbandingan Perolehan Nilai

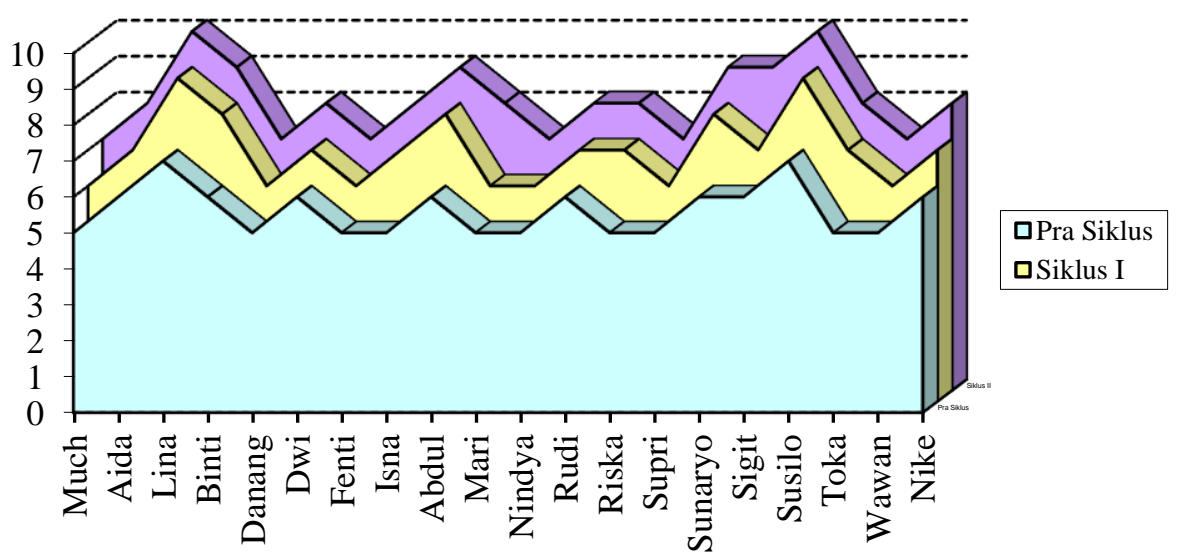




\section{PEMBAHASAN}

Pra Siklus

Untuk mengatasi permasalahan pada pembelajaran Pra siklus, dalam diskusi dengan teman sejawat dan supervisor ditemukan masalah tidak adanya penggunaan alat peraga dalam penyampaian materi pembelajaran. Rata-rata nilai kelas hanya 5,6. Nilai tertinggi yang diraih siswa hanya nilai 7. Tingkat penyerapan materi pelajaran hanya $56 \%$. Siswa yang mendapatkan nilai baik hanya sejumlah 2 anak (10\%). Sejumlah 8 siswa (40\%) mendapatkan nilai cukup. Sedangkan sejumlah 10 siswa (50\%) masih mendapatkan nilai kurang.

Situasi kelas pada saat pembelajaran Pra siklus pelajaran Matematika tidak sesuai dengan apa yang diharapkan. Siswa banyak yang tak mendengarkan penjelasan dari guru. Sebagaian siswa ada yang bermain sendiri, bersenda gurau dengan teman, bahkan ada beberapa siswa yang malas untuk mencatat penjelasan dari guru. Melihat hasil temuan pada pembelajaran Pra siklus disusun rencana tindakan pada perbaikan pembelajaran I. Rencana ini mengarah pada Penggunaan alat peraga.

\section{Perbaikan Pembelajaran Siklus I.}

Berdasarkan pada perbaikan pembelajaran I dengan penggunaan alat peraga yang sesuai dengan materi pelajaran, hasil yang diharapkan masih belum optimal. Hal ini terlihat dari kenaikan nilai rata-rata nilai siswa belum sepenuhnya sesuai dengan yang diharapkan. Nilai rata rata hanya naik menjadi 7,0. Daya serap materi pelajaran baru mencapai $70 \%$. Nilai tertinggi adalah 9 . Siswa yang memperoleh nilai cukup sejumlah 7 siswa (35\%), sedangkan siswa yang mendapatkan nilai baik sejumlah 11 siswa (55\%) dan sejumlah 2 anak (10\%) mendapatkan nilai cukup baik.

Situasi kelas saat berlangsung pembelajaran kurang memenuhi dengan apa yang menjadi harapan. Hal ini terjadi akibat pembelajaran masif bersifat klasikal. Penggunaan alat peraga belum mampu menarik minat siswa. Siswa bersifat pasif karena hanya mendengarkan penjelasan dan melihat media peraga yang dipakai guru untuk menyampaikan materi pelajaran.

Melihat hasil temuan pada perbaikan pembelajaran siklus I disusun rencana tindakan pada perbaikan pembelajaran siklus II. Rencana ini mengarah pada penggunaan alat peraga yang relevan dan pemberian tugas kepada siswa melalui LKS.

\section{Perbaikan Pembelajaran Siklus II}

Pada perbaikan pembelajaran siklus II peneliti menggunakan alat peraga yang relevan untuk penyampaian materi pembelajaran. Selain itu peneliti memberi tugas melalui LKS agar siswa ikut terlibat dan aktif dalam pembelajaran. Tingkat penguasaan materi pelajaran menjadi optimal, hal ini terlihat dari hasil nilai yang dicapai oleh siswa. Nilai rata-rata dari 7,0 pada siklus I naik menjadi 8,1 pada siklus II. Tingkat daya serap meteri pelajaran oleh siswa mencapai $81 \%$. Nilai tertinggi yang diraih siswa adalah 10. Siswa yang mendapatkan nilai baik sejumlah 11 siswa (70\%) pada siklus II. Sejumlah 4 siswa (20\%) mendapatkan nilai cukup baik dan 2 orang siswa (10\%) berhasil mendapatkan nilai istimewa.

Situasi kelas saat berlangsung perbaikan pembelajaran II sudah sesuai dengan apa yang menjadi harapan. Penggunaan alat peraga mampu menarik minat siswa dalam mengikuti pembelajaran. Bimbingan kepada siswa dalam meteri pelajaran membuat siswa menjadi aktip. Suasana kelas menjadi tenang karena semua siswa mengerjakan tugas LKS yang diberikan oleh guru. 


\section{Kesimpulan}

Dalam pembelajaran matematika ada dua hal penting yang merupakan bagian dari tujuan pembelajaran matematika adalah pembentukan sifat dengan berpikir kritis dan kreatif. Selian hal itu dapat juga dari hasil perbaikan pembelajaran yang telah dilaksanakan dapat ditarik kesimpulan dengan penggunaan alat peraga yang sesuai, penguasaan siswa terhadap materi pelajaran akan meningkat, dengan pemberian tugas kepada siswa menjadikan siswa akan lebih aktif, dengan membimbing siswa dapat membantu siswa yang kurang aktif.

\section{Saran}

Berdasarkan kesimpulan tersebut diatas, beberapa hal yang harus dilakukan guru dalam peningkatan kualitas pembelajaran khususnya meningkatkan minat dan keaktipan siswa dalam mengikuti materi pembelajaran adalah guru dalam melaksanakan pembelajaran hendaknya mencari variasi lain dari kegiatan klasikal, apabila alat peraga untuk penyampaian materi pelajaran kurang sesuai, segera mengganti alat peraga tersebut sesuai dengan materi pembelajaran, pergunakan alat peraga yang dapat merangsang minat belajar siswa, guru harus memberikan bimbingan kepada siswa yang menemui kesulitan dalam pembelajaran. Di samping itu berdasarkan pengalaman melaksanakan perbaikan pembelajaran melalui PTK, kiranya perlu mengaktipkan Kelompok Kerja Guru (KKG) untuk bertukar pikiran dan pengalaman, berkenaan dengan masalah dan tugas seharihari sebagai pendidik.

\section{DAFTAR PUSTAKA}

Drs. Gatot Muhsetyo, M.Sc., dkk, (2005), Pembelajaran Matematika SD. Jakarta: Rosda Karya.

Dinn Wahyudin \& D. Supriadi, (2004), Pengantar Pendidikan. Jakarta: Rosda Karya.

Hadi, Sutrisno, 1982. Metodologi Research, Jilid I. Yogyakarta: YP Fak. Psikologi UGM

Hamalik, Oemar. 2002. Psikologi Belajar dan Mengajar. Bandung Sinar Baru Algesindo.

Hasibuan. J.J dan moerdjiono. 1998 Proses Belajar mengajar. Bandung : Remaja Rosdakarya

I.G.AK. Wardani, dkk., (2004), Penelitian Tindakan Kelas. Jakarta: Rosda Karya. Mulyani Sumantri \& Nana Syaodih, (2005), Perkembangan Peserta Didik. Jakarta: Rosda Karya.

Margono, 1997. Metodologi Penelitian

Pendidikan. Jakarta Rineksa Cipta

TIM FKIP, (2007), Pemantapan Kemampuan Profesional. Jakarta: Rosda Karya.

Tim Bina Karya Guru, (2007), Terampil Berhitung Matematika Untuk SD Kelas IV. Jakarta: Erlangga.

Udin S. Winataputra, dkk., (2001), Strategi Belajar

Mengajar. Jakarta: Rosda Karya. 